\title{
ФЕДОР ФЕДОРОВИЧ (ФРИДРИХ-ФРОМГОЛЬД) МАРТЕНС: РОЛЬ ЛИЧНОСТИ В ИСТОРИИ
}

\section{FEDOR FEDOROVICH (FRIEDRICH FROMHOLD) MARTENS: THE ROLE OF PERSONALITY IN HISTORY}

\section{A. Sapezhinskaya}

Summary: The purpose of the article is to determine the importance of the role of the personality of Fyodor Fedorovich (Friedrich-Fromgold) Martens for the development of international law. The article examines the stages of his formation as a scientist, as well as changes in international law in the course of historical development. The main attention is paid to such works of F.F. Martens as «Contemporary international law of civilized peoples», as well as the Collection of all international treaties of the Russian Empire. Many scientific positions defined by F.F. Martens over a century ago, for example, four basic principles for the theoretical analysis of international law are still relevant today. Scientific novelty lies in the study of the role of personality Fedor Fedorovich (FriedrichFromgold) Martens is inseparable from the history of the Russian state, and the role of the Russian state in the international arena. As a result, it was determined that despite the imminent fall of the Russian Empire and the temporary oblivion of the name of Fyodor Fedorovich (FriedrichFromgold) Martens for Russian scientists, he is the founder of both humanitarian and international law.

Keywords: science, jurisprudence, personality, history, international law, F.F. Martens, international agreement, humanitarian law.
B отличие от многих других наук международное право является достаточно молодой и «новой» дисциплиной, которая очень активно стала развиваться в последние два века, однако, еще в XVIII веке Шарль Луи Монтескье в своем труде «О духе законов» писал: «Международное право, естественно, основывается на том принципе, согласно которому различные народы должны во время мира делать друг другу как можно более добра, а во время войны причинять насколько возможно менее зла, не нарушая при этом своих истинных интересов. Цель войны - победа; цель победы - завоевание; цель завоевания сохранение. Из этого и предшествующего принципов должны проистекать все законы, образующие международное право». Федор Федорович (Фридрих-Фромгольд) Мартенс продолжил данную мысль, всячески пытаясь внести законодательную ясность в закрепление данных положений, в запрет использования жестокого оружия во время войны, в защиту гражданского населения и, в целом, в систематизацию международного права. Уже тогда он думал о создании единой международной организации, говорил о том,

\author{
Сапежинская Анна Антоновна \\ Аспирант, Дипломатическая академия Министерства \\ иностранных дел Российской Федерации \\ Amy2006@yandex.ru
}

Аннотация: Цель исследования - определить важность роли личности Федор Федорович (Фридрих-Фромгольд) Мартенс для развития международного права. В статье рассматриваются этапы его становления как ученого, а также изменение международного права в ходе исторического развития. Основное внимание уделяется таким трудам Ф.Ф. Мартенса как «Современное международное право цивилизованных народов», а также (борнику всех международных договоров Российской Империи. Многие положения, выдвинутые Ф.Ф. Мартенсом более века назад, например, четыре основные принципа для теоретического анализа международного права являются актуальными до сих пор. Научная новизна заключается в изучении роли личности Федор Федорович (Фридрих-Фромгольд) Мартенс неразрывно с историей Российского государства, и роли Российского государства на международной арене. В результате определено, что несмотря на скорое падение Российской Империи и временного забвения имени Федора Федоровича (ФридрихФромгольд) Мартенса для российских ученых, он является основоположником как гуманитарного, так и международного права.

Ключевые слова: наука, юриспруденция, личность, история, международное право, Ф.Ф. Мартенс, международный договор, гуманитарное право.

что государства должны пожертвовать частью своего суверенитета для мира и стабильности. Возможно, если бы были подписаны все выдвинутые им соглашения, то таких страшных потер, которые принесли две Мировые войны, возможно было бы избежать. Поэтому, в данной статье я делаю попытку раскрыть личность Ф.Ф. Мартенса в контексте исторических условий, систематизировать его вклад в Международное право.

Чтобы можно было понять роль личности Ф.Ф. Мартенса, необходимо определить в какую эпоху он жил и творил. Поэтому следует обратиться к истории Российской Федерации. Ученый являлся свидетелем правления четырех императоров, а именно Николая I, Александра II, Александра III и Николая II. В целом, данное время достаточно противоречиво. Либеральный и консервативные курсы сменяли друг друга попеременно.

События, которые предшествовали началу деятельности Федора Федоровича в сфере международного права, а именно внешняя политика Российской Империи 
заключалась в следующем - при Николае І у России было три основных направления: была попытка добиться контроля над проливом Босфор и Дарданеллы, в чем Россия потерпела неудачу в связи с проигрышем в Крымской войне, борьба с революционными движениями в Европе и расширение Империи на Кавказ и в Средней Азии. Как результат Крымской войны, Российская Империя оказалась в полной изоляции от своих европейских партнеров, которые, боясь ее возрастающего могущества, поддержали Османскую империю. После смерти своего отца Александр II вернулся к политике всемерного расширения и присоединил Среднюю Азию, Северный Кавказ, Дальний Восток, Бессарабию, Батуми. Россия смогла вернуть свои права на Черном море. Однако, в обществе не понимали зачем Российская империя забирает восточные земли, так как это приводило к большим потерям людей и материальным затратам. В свое правление Император продал Аляску США и передал Курильские острова Японии, чем обеспечил нейтралитет этих стран к России на какое-то время. Был заключен тайный мир с Австрией.

В целом, к моменту, когда Федор Федорович стал завкафедрой Международного права в Императорском Санкт-Петербургском университете и членом Совета Министерства иностранных дел, Российская Империя, при всем своем влиянии, проводила достаточно прогерманскую внешнюю политику, в то время как внутренняя либеральная политика Александра II не дала ожидаемого результата, что привело к увеличению количества восстаний, террористических актов и убийству Императора.

«Расцвет» карьеры Федора Федоровича пришелся на правления Александра III. Это безоговорочно плодотворно повлияло на российского юриста. Несмотря на жесткую и консервативную внутреннюю политику государства, внешняя политика Российской Империи создала образец самодержавия, открытости, миролюбия и здравого смысла на мировой арене. Россия отказалась от тактики тайных соглашений, не вела ни одну войну и в целом противостояла серьезным конфликтам, таким, как, например, намечающаяся война Германии и Франции. Российская Империя отказалась от таких союзов, которые не приносили ей пользу, подобно союзу с Болгарией. Разочаровавшись в Германии, Император начал с ней «Таможенную войну» и уже при Николае II был подписан выгодный России торговый договор. Но самым главным преимуществам стал союз с Францией, который принес пользу как одного державе, так и другой. На Восточном фронте Россия, хоть и увеличила свою территорию еще на 430 тыс. км²., проводила всю ту же миролюбивую политику, подписав соглашения с Англией.

При Николае II, несмотря на поражение в Русскояпонской войне, на международной арене Российская империя продолжила играть значительную и очень важную роль. Кроме соглашения с Германией, Император заключил соглашение с Австро-Венгрией, которое повлияло на завершение Греко-турецкой войны. В 1901 году Россия установила дипломатические отношения с Афганистаном и вернул их с Болгарией. Империя понимала важность Китая и Кореи и была положительно настроена на сотрудничество с ними.

Мне кажется, именно такая внешняя политика Российской Империи способствовала проведению в 1899 и 1907 годах Гаагских мирных конференций, где Федор Федорович был одним из организаторов, и которые являются одними из первых и очень важных шагов в Международном праве и праве ведения войны.

Фридриха-Фромгольда Мартенса называли ученым мирового уровня. Он внес огромный вклад в дело и развития и нормативного закрепления идей и принципов гуманитарного права. Ряд положений до сих пор действующих конвенций по гуманитарному праву содержит его оговорки. Принадлежал в действующему в тот момент направлению - позитивизму.

Сторонник частичного отказа от суверенитета государства в пользу создания формы международного общения. Можно сказать, что уже тогда в конце XIX века он думал о создании единой международной организации, которой в последствии стала Лига Наций и ее продолжение, ООН (разработал проект концепции международного общения и международного управления, управляемой ассоциации суверенных государств).

Основная позиция ученого: только то государство, в котором личность получила признание своих прав, может стать членом правильно организованного международного общения. В странах (преимущественно неевропейских), где степень человеческой свободы значительно ниже, необходимо применять не международное, а «естественное право», но содержание которого он не определял.

Ф.Ф. Мартенс считал, что международное право должно освещать и устанавливать нормативные стандарты, создать положения, чтобы заполнить правовой вакуум и помочь смягчить ужасы войны.

Далее, прежде чем отметить все те выдающиеся вещи, которые принес Ф.Ф. Мартенс в Международное право, я бы хотела остановиться на его биографии. Показать, как человек, даже в непростые времена конца XIX века может добиться многого исключительно своим умом, рвением и любовью к истории и праву. ФридрихФромгольд Мартенс родился в бедной эстонской семье, в пять лет он потерял отца, а в девять - мать. Став круглой сиротой, он был определен в Сиротский приют при Главном немецком училище Св. Петра. Уже в таком 
малом возрасте его заметили и перевели из школы сиротского дома в Главное немецкое училище Св. Петра.

Из-за его любви к истории учителя уговаривали Фридриха-Фромгольда (Федором Федоровичем он станет только после своей женитьбы в 1879 году) пойти на филологический факультет, однако, он принял решение поступать и поступил на юридической факультет Императорского Санкт-Петербургского университета.

В это время наука Международного права только начинала развиваться, и декан юридического факультета И.И. Ивановский оставил молодого ученого при университете в аспирантуре с главной целью - изучение международного права. С чем Ф.Ф. Мартенс справился блестяще. В 1868 году получил степень кандидата наук за работу «О праве частной собственности во время войны» и был направлен заграницу для «перенимания опыта международного права» там. Уже в 1871 году Фридрих Мартнес вернулся в Россию и возглавил кафедру Международного права в своей Альма-Матер.

С 1873 года начал составление по поручению Александра II сборника всех международных договоров, которые когда-либо заключала Россия с другими государствами и защитил докторскую диссертацию «О консулах и консульской юрисдикции на Востоке», а в 1876 году был назначен ординарным профессором Императорского Санкт-Петербургского университета.

22 декабря 1879 года женился и согласно законам того времени он, вступая в брак, должен был сменить верну и как результат имя и отчество, поэтому с этого дня он стал именовать себя Федором Федоровичем. В этом же году он был назначен чиновником особых поручений при А.М. Горчакове, а с 1881 года - неприменным членом Совета Министерства. Начиная с 80-ых годов Федор Федорович Мартнес стал принимать активное участие в развитие международного права и представление Российской Империи на международной арене. Он участвовал в качестве делегата от России практически на всех значимых международных конференциях, речь о которых пойдет позже. Кроме того, с 1884 года и до своей смерти участвовал во всех конференциях Красного Креста, являясь его членом. Ф.Ф. Мартенс дважды избирался вице-президентом Института международного права в г. Генте, а также был номинирован на Нобелевскую премию мира.

Кроме того, он был выдающимся международным арбитром. Ф.Ф. Мартенс принимал участие во многих третейских разбирательствах, принёсших ему огромный авторитет. Его называли «Лордом-канцелром Европы» и даже «главным судьей христианского мира». Началом арбитражной деятельности можно считать спор Англии и Франции 1891 года о правах рыбной ловли в прибрежных водах Ньюфаундленда, однако рассмотре- ние данного дела не состоялось. Самыми значимыми в его карьере были споры между Великобританией и США относительно правового регулирования рыболовства в Беринговым море, между Мексикой и США касательно Калифорнийский духовных фондов, между Нидерландами и Англией 1985 года об аресте нидерландскими властями в Макасаре английского подданного шкипера китобойного судна «Коста-Рика Пэкет» и между Англией и Венесуэлой в 1899 году о границе, проходящей по территории Британской Гвианы.

Также неоднократном избирался арбитром по спискам Постоянной палаты Третейского суда в Гааге.

В 1899 и 1907 году участвовал в двух Гаагских конференциях мира, практически являлся организатором первой. Стоит отметить также его участие в русско-японских переговорах 1905 года в Портсмуте.

Учениками Ф.Ф. Мартенса были такие известные личности как: А.Н. Мандельштам, Б.Э. Нольде, А.А. Пиленко, M.A. Таубе.

Ученый скоропостижно скончался 7 июня 1909 года по пути в Петербург на железнодорожной станции Валк Лифляндской губернии от внезапной остановки сердца. Он похоронен на Волковском лютеранском кладбище.

Что касается вклада Ф.Ф. Мартенса в науку «Международного права», то здесь стоит выделить несколько направлений его деятельности.

Ф.Ф. Мартенс является автором знаменитого двух томного пособия «Современное международное право цивилизованных народов» (первое полное руководство в России по международному праву), переведенного на многие языки мира. Данное пособие заложило фундамент современной науки международного права.

Автор указывал, что ее развитие происходит с учетом социального и политического прогресса государств и что данная наука непосредственно связана и с историей международных отношений.

Глава этого же труда «Международного частное право» являлась русской доктриной международного частного права, где были рассмотрены гражданскоправовые отношения, включающие иностранный элемент, которые Ф.Ф. Мартенс наименовал «международные гражданские отношения», в нем были затронуты и проблемы соотношения внутригосударственного и международного права. Он полагал, что «те внутренние законы, которые определяют социальное устройство, взаимные права и обязанности общественных классов и государства, очевидно, должны оказывать влияние на право, обеспечивающее социальные интересы каждого народа в области международных отношений. Совре- 
менно положительное международное право нельзя понять, не зная действующего государственного права образованных народов».

Ф.Ф. Мартенс также предложил 4 основных принципа для теоретического анализа международного права:

1. все государства и народы в своем развитии выступают в общении друг с другом;

2. активность участия государства в международном общении определяется степенью развития в стране демократических свобод;

3. международное право было рождено общностью интересов народов и их международным общением;

4. общение государств и народов между собой делает необходимым наличие международного управления и «международного административного права.

Второй по счету, но не по значимости является его работа «Собрания трактатов и конвенций, заключенных Россиею с иностранными державами», которая состоит из 15 томов, выпущенных с 1873 года по 1909 год. Данная работа представляет собой наиболее полную систему всех договоров Российской Империи до 1909 года и уже только за нее имя Ф.Ф Мартена навсегда останется в нашей истории.

Интересом для международного права является его докторская работа «О консулах и консульской юрисдикции на Востоке». В ней он исследовал законы международной администрации. «Международные отношения надо изучать не изолированно, а в их естественной связи с юридическими учреждениями отдельных государств и разнообразными, как духовными, так и экономическими интересами общества». Степень свободы человеческой личности являлась для Ф.Ф. Мартенса мерилом интенсивности участия государства в «международных сношениях».

Ф.Ф. Мартнес также одним из первых охарактеризовал Каспийское море с точки зрения международного права. Он говорил: «это закрытое море: они состоят под властью того государства, в пределах которого лежат. На этом основании... Каспийское море также закрытое, хотя оно омывает берега, принадлежащие России и Персии, но должно считаться русским».

Далее, стоит остановиться на работе Ф.Ф. Мартена на международной арене, например, в ходе конференций. Одной из которых была Брюссельская конференция по определению и кодификации законов и обычаев войны 1874 г.

Это конференция - первая попытка кодифицировать законы и обычаи войны. По инициативе Александра II. Ф.Ф. Мартенс был автором проекта Конвенции о законах и обычаях сухопутной войны, которая предлагалась для подписания. Проект предусматривал подробную регламентацию прав воюющих сторон в отношении друг друга и частных лиц, а также порядок сношений между воюющими сторонами и разрешения вопроса о репрессалиях. Большинство стран отказались поддерживать предложенных проект, он стал лишь рекомендацией, но являлся большим шагом для дальнейшего действия, некоторые ее положения легли в основу Гаагской декларации 1899 года.

Даже во время работы международным арбитром, Ф.Ф. Мартенс вносил что-то новое в международное право. В ходе дела между Нидерландами и Англией 1985 года об аресте нидерландскими властями в Макасаре английского подданного шкипера китобойного судна «Коста-Рика Пэкет» он впервые сформулировал принцип подсудности капитана за правонарушения в открытом море согласно закону флага судна. А во время рассмотрения дела между Англией и Венесуэлой в 1899 году о границе, проходящей по территории Британской Гвианы, предложил составленный им регламент судопроизводства, который в дальнейшим был закреплен Гаагской конвенцией. Иными словами, это был первый случай, когда дело рассматривалось на основании составленного регламента и устава судопроизводства.

Особо стоит отметить Первую Гаагскую конференцию мира 1899 года. Ф.Ф. Мартенс был автором ее программы. Он положил начало разоруженческому процессу, установлению правил ведения войны и мирного разрешения государственных споров. Несмотря на множество противоречий, были подписаны конвенции о мирном разрешении международных споров, о законах и обычаях войны на суше, о применении к морской войне начал Женевской конвенции 1864 года, а также три декларации, запрещавшие применение разрывных пуль, «удушливых газов, а также метание взрывчатых снарядов с воздушных шаров».

Также было внесено предложение о правомерности партизанской войны, включенное в преамбулу Конвенции.

В науку просто вошло понятие декларации или оговорки Мартенса. Декларация или оговорка Мартенса это часть 6 данной Гаагской конвенции, которая гласит: «В настоящее время оказалось, однако, невозможным прийти к соглашению относительно постановлений, которые обнимали бы все возникающие на деле случаи. С другой стороны, в намерения Высоких Договаривающихся Держав не могло входить, чтобы непредвиденные случаи, за отсутствием письменных постановлений, были представлены на произвольное усмотрение военачальствующих.

Впредь до того времени, когда представится возможность издать более полный свод законов войны, Высоки Договаривающиеся Стороны считают уместным за- 
свидетельствовать, что в случаях, не предусмотренных принятыми ими постановлениями, население и воюющие остаются под охраною и действием начал международного права, поскольку они вытекают из установившихся между образованными народами обычаев, из законов человечности и требований общественного сознания». Иным словами, в случаях, которые не попадают под действия существующих конвенций и соглашений, гражданские лица остаются под защитой принципов международного права, которые вытекают из обычаев, гуманности и совести.

Эта оговорка внесена в ряд международных конвенций, в частности в Конвенцию о запрещении некоторых видов оружия 1980 года, на нее ссылался Международный суд ООН при выработке Консультативного заключения 1996 года относительно законности угрозы ядерного оружия.

Этот пункт можно также рассматривать как смесь позитивного права («установление обычаев между цивилизованными нациями») и естественного права («законы человечности» и «требования общественного сознания»).

Мнения юристов по этой конвенции расходятся. Д.В.Левин, Г.В. Шармазанашвили и др. критикуют Гаагские конвенции о мировом разрешении межгосударственных споров за излишнюю «гибкость», отсутствие в них категорического запрещения войны как средства решения. Однако, другие ученые по-прежнему подчеркивают важность положения Мартенса для международ- ного гуманитарного права.

На долгое время имя великого ученого было практически забыто, так как в СССР не одобряли его деятельность за выступления против «анархистов» и «бомбистов», а также за поддержку и юридическое обоснование требований царского правительства о выдаче участников революционных выступлений в России, укрывавшихся за границей. Его имя не вошло в первое издание Большой советской энциклопедии 1938 года, а также в трехтомную «Историю дипломатии» 1960-х годов.

После распада СССР Ф.Ф. Мартенс был реабилитирован и снова занимает достойное место в ряду юристовоснователей, с 1997 года ежегодно проходит конкурс его имени по международному гуманитарному праву и научно-практическая конференция по международному праву «Мартенсовские чтения», а также учреждена премия имени Ф.Ф. Мартенса.

Таким образом, условно можно разделить деятельность Ф.Ф. Мартенса в рамках развития международного права в Российской Империи, а именно его преподавание в Санкт-Петербургском университете и написание трудов на Родине, а также деятельность на международной арене, которая оставила неизгладимый след на систему международных отношений в целом. Несмотря на некоторую критику и почти вековое «забвение», имя Федора Федоровича Мартнеса навсегда останется в истории права, как одного из основателей международного и гуманитарного права.

\section{ЛИТЕРАТУРА}

1. Антонова Л.В., Просвирова Т.А. История дипломатии России. — М: Дом Славянской книги. — 2010. — С. 325;

2. Декларация о запрещении метания снарядов и взрывчатых веществ с воздушных шаров (Гаага, 18 октября 1907 г.) [электронный ресурс]- Режим доступа: URL: http://base.garant.ru/2540777/\#ixzz60InW87SK- (дата доступа 08.06.2020);

3. Ковалев А. 100 лет памяти. Ф.Ф. Мартенс — российский юрист и дипломат, Журнал Международная жизнь, — №7 — 2009;

4. Конвенция о законах и обычаях сухопутной войны, 18 октября 1907 года [электронный ресурс]- Режим доступа: URL: https://www.icrc.org/ru/doc/ resources/documents/misc/hague-convention-iv-181007.htm- (дата доступа 08.06.2020);

5. Мартенс Ф.Ф., 0 праве частной собственности во время войны- Санкт-Петербург: печ. В. Головина, 1869. — VIII, С. 455;

6. Мартенс Ф.Ф., 0 консулах и консульской юрисдикции на Востоке- Санкт-Петербург: тип. М-ва пут. сообщ. (А. Бенке), 1873. —VIII, С. 601;

7. Мартенс Ф.Ф., «Собрание трактатов и конвенций, заключённых Россией с иностранными державами» (Санкт-Петербург, с 1874 г.) на сайте «Руниверс»;

8. Мартенс Ф.Ф., Восточная война и Брюссельская конференция. 1874-1878 гг. — Санкт-Петербург: тип. М-ва пут. сообщ. (А. Бенке), 1879. — VIII, 596, С. 46;

9. Мартенс Ф.Ф., Россия и Англия в Средней Азии / Ф. Ф. Мартенса; с изм. и доп. авт. пер. К. Ф. Таубе. — СПб.: Э. Гартье, 1880. — III, С. 91;

10. Мартенс Ф.Ф., Современное международное право цивилизованных народов. — Санкт-Петербург, 1882 — 1883. (издание 5-е, 1904-1905 годы; переведено на немецкий, французский и испанский языки). Том 1. - 1882. — IV, XIX, C. 418;

11. Мартенс Ф.Ф., Современное международное право цивилизованных народов. — Санкт-Петербург, 1882-1883. (издание 5-е, 1904-1905 годы; переведено на немецкий, французский и испанский языки). Том 2. - 1883. - С. 563;

12. Монтескье Ш.Л. 0 духе законов. — М: Рипол Классик. — 2018. — С. 12;

13. Николаев Н.Ю. Ф.Ф. Мартенс о войне и мире // История государства и права. - 2014. - № 7. - С. 9-12;

14. Пустогаров В.В. «... С пальмовой ветвью мира» Ф.Ф Мартенс - юрист, дипломат, публицист. — М.: Междунар. отношения. — 2008. — С.81, 288.

(c) Сапежинская Анна Антоновна (Amy2006@уandex.ru).

Журнал «Современная наука: актуальные проблемы теории и практики» 